\title{
Analisis Perencanaan Pengembangan Fasilitas Terminal Khusus PLTU Nagan Raya Aceh
}

\author{
Amiruddin Akbar Fisu ${ }^{1}$ \\ ${ }^{1}$ Universitas Andi Djemma, Palopo, Indonesia
}

\begin{abstract}
Abstrak
Tujuan penelitian ini adalah untuk mengetahui bagaimana kebutuhan fasilitas sisi laut pelabuhan pada rencana pembangunan terminal khusus Batu Bara PLTU Nagan Raya. Untuk mengetahui kebutuhan fasilitas pelabuhan terlebh dahulu dianalisis kebutuhan batu bara yang dibutuhkan untuk memproduksi listrik, jenis kapal yang digunakan untuk mengangkut batu bara tersebut, perencanaan terminal khusus dengan analisis proyeksi volume bongkar muat, dan frekuensi kunjungan kapal di terminal khusus. Selanjutnya dilakukan analisis kebutuhan fasilitas tarsus atau pelabuhan..
\end{abstract}

Kata kunci: fasilitas pelabuhan, terminal khusus, PLTU, Aceh

\section{Pendahuluan}

Dalam perkembangan suatu wilayah regional, permintaan atas energi, khususnya energi listrik akan terus meningkat. Di masa yang akan datang, pertumbuhan aktivitas ekonomi akan mempengaruhi permintaan terhadap energi yang lebih banyak. Adanya pengembangan sarana pembangkit listrik yang baru akan meningkatkan reliability dari sistem perlistrikan di Nagan Raya dan sekitarnya serta mengantisipasi kenaikan beban dan beban puncak. Oleh karenanya, PLN merencanakan utnuk membangun pembangkit listrik bertenaga uap untuk melayani kebutuhan beban puncak tersebut.

Untuk menunjang kegiatan Pembangkit Listrik Tenaga Uap (PLTU) Nagan Raya Aceh,, perlu dikembangkan terminal khusus untuk kepentingan operasional PLTU tersebut. Pembangunan atau pengembangan sarana transportasi juga dapat menimbulkan dampak positif terhadap suatu wilayah (Fisu, 2018). Menurut Humang (2016), pembangunan sarana transportasi memiliki hubungan timbal balik dengan perekonomian suatu daerah untuk menunjang perkembangan kawasan perkotaan dan pedesaan. Transportasi sangat terkait dengan aksesibilitas, dimana aksesibilitas merupakan faktor yang sangat menentukan organisasi ruang di kawasan perkotaan. Peningkatan aksesibilitas dan penggunaan lahan adalah proses yang saling terkait (Fisu, 2019). Pelabuhan merupakan fasilitas penunjang transportasi laut yang sangat efektif untuk menghubungkan suatu daerah dengan daerah lain di kawasan kepulauan seperti Indonesia (Oktaparizki dkk, 2018). Berdasarkan PP No.61 Tahun 2009 
tentang Kepelabuhanan dan PM. No.51 Tahun 2011 tentang Terminal Khusus dan Terminal Untuk Kepentingan sendiri, Terminal Khusus adalah terminal yang terletak di luar Daerah Lingkungan Kerja dan Daerah Lingkungan Kepentingan Pelabuhan yang merupakan bagian dari pelabuhan terdekat untuk melayani kepentingan sendiri sesuai dengan usaha pokoknya. Dalam pengembangan pelabuhan terlebih dahulu mengupayakan optimalisasi kinerja operasional pelabuhan (Arianto, 2017). Usaha pokok yang dapat dilakukan adalah usaha dalam bidang pertambangan, energi, kehutanan, pertanian, perikanan, industry, pariwisata, serta dok dan galangan kapal.

Tujuan penelitian ini adalah untuk mengetahui bagaimana kebutuhan fasilitas pelabuhan pada rencana pembangunan terminal khusus BATU BARA PLTU Nagan Raya. Untuk mengetahui kebutuhan fasilitas pelabuhan terlebh dahulu dianalisis kebutuhan listrik, jumlah batu bara yang dibutuhkan untuk memproduksi listrik, jenis kapal yang digunakan untuk mengangkut batu bara tersebut, perencanaan terminal khusus dengan analisis proyeksi volume bongkar muat, dan frekuensi kunjungan kapal di terminal khusus. Selanjutnya dilakukan analisis kebutuhan fasilitas laut untuk menunjang aktifitas operasional pelabuhan.

\section{Fasilitas sisi perairan}

\section{Alur Pelayaran}

Alur pelayaran adalah perairan yang dari segi kedalaman, lebar, dan bebas hambatan dari pelayaran lainnya yang dianggap aman dan selamat untuk dilayari oleh kapal di laut, sungai atau danau (Witantono dan Khosmin, 2015). Penentuan dan pengaturan alur pelayaran di laut, sungai, danau serta penyelenggaraannya dan juga pengaturan sistem rute dan tatacara berlalu lintas perlu diprogramkan guna kelancaran dan keselamatan berlayar. Disamping itu pengaturan terhadap bangunan atau instalasi dan gelaran kabel atau pipa bawah air di perairan khususnya di alur pelayaran. Dalam pekerjaan survei alur pelayaran dan perlintasan dapat dikategorikan memiliki alur-pelayaran yang lalu lintasnya padat dan sempit sehingga perlu dilakukan pengaturan lalu lintas kapal melalui sistem rute kapal (ship's routing system). 

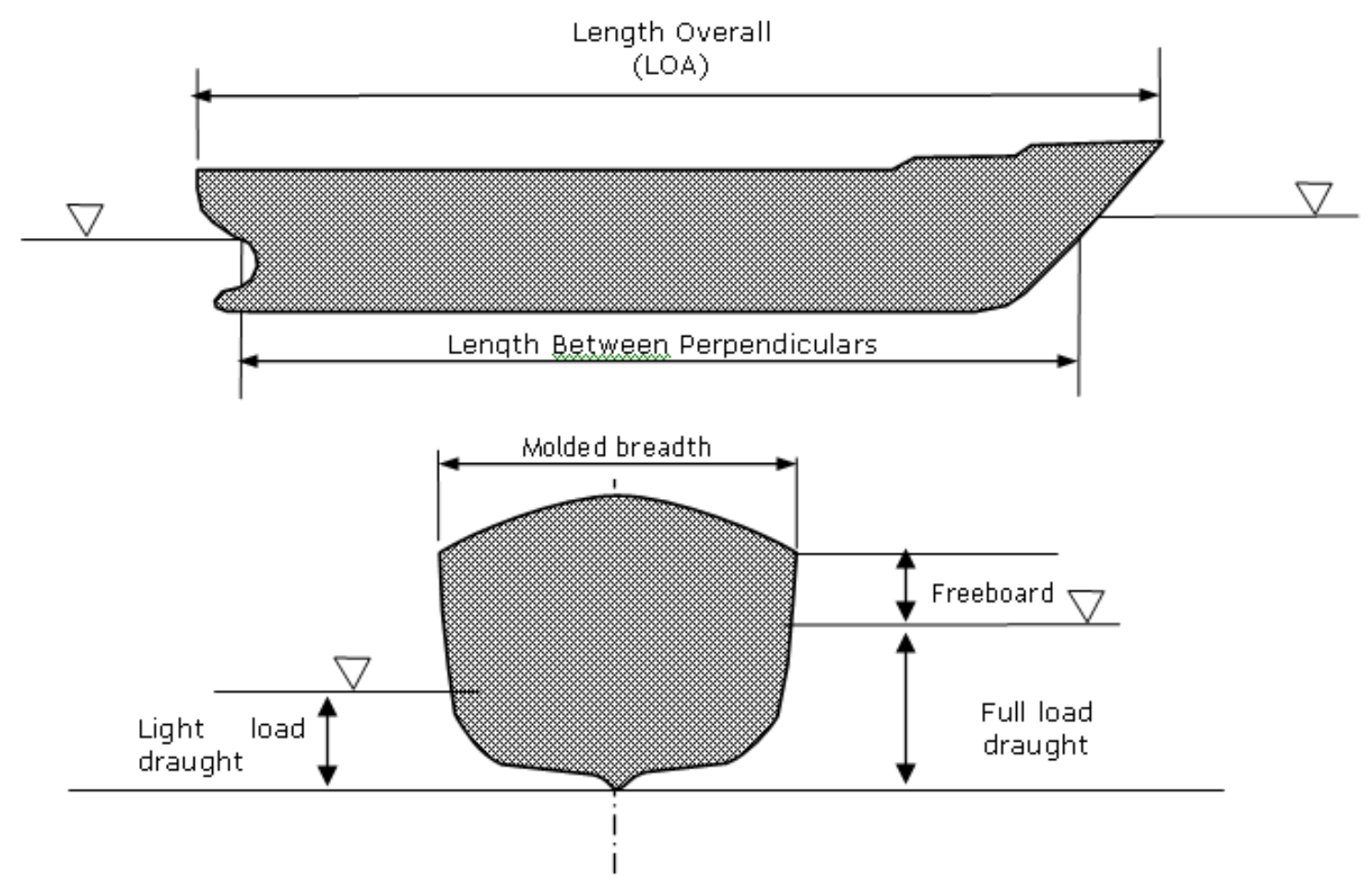

Gambar 1: Sketsa Definisi dari Parameter-Parameter Kapal

\section{Kedalaman Alur}

Untuk mendapatkan kondisi operasi yang ideal kedalaman air di alur pelayaran harus cukup besar untuk memungkinkan pelayaran pada muka air terendah (LWL) dengan kapal bermuatan maksimum atau kedalaman alur harus lebih besar dibandingkan dengan batas muatan kapal terbesar yang melewatinya, disamping itu kedalam alur Pelayaran harus memperhatikan jarak toleransi dari gerakan kapal yang disebabkan oleh gelombang, angin dan arus. Kedalaman alur pelayaran secara umum dapat ditentukan dengan menggunakan rumus sebagai berikut:

$$
\mathrm{H}=\mathrm{d}+\mathrm{G}+\mathrm{R}
$$

\section{Dimana:}

$\mathrm{H}=$ Kedalaman alur, $\mathrm{m}$

$\mathrm{d}=$ draft kapal, $\mathrm{m}$

$\mathrm{G}=$ gerak vertikal kapal karena gelombang dan squat, $\mathrm{m}$

$\mathrm{R}=$ ruang kebebasan bersih untuk:

Kolam 7\%-15\% dari draft kapal

Alur 10\%-15\% dari draft kapal 


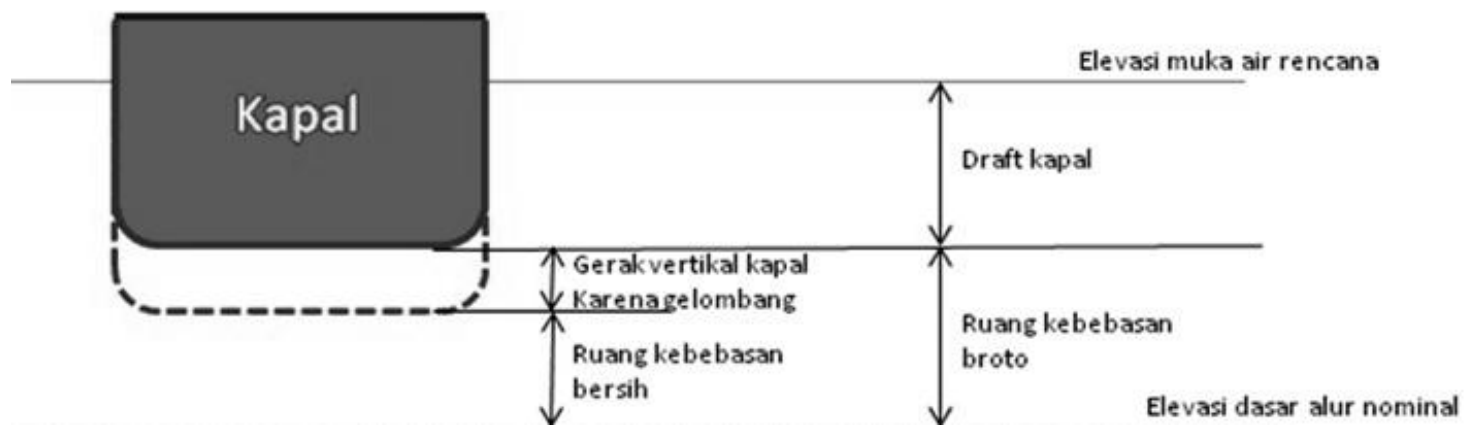

Gambar 2 : Skema Kedalaman Alur Pelayaran

\section{Lebar Alur}

Lebar alur pelayaran diukur pada posisi air surut terendah (LWS). Perubahan geometri/alignment alur adalah perubahan arah alur yang disebabkan :

- sedimentasi/erosi atau banjir,

- perubahan permukaan air karena berkurangnya debet air,

- data perubahan alur yang diperlukan adalah data perubahan mengenai,

- kedalaman alur,

- lebar ulur,

- lebar sungai pada kedalaman air pasang tertinggi/banjir,

- kecepatan arus, serta

- faktor-faktor penyebab perubahan.

\section{Kolam Pelabuhan}

Kolam pelabuhan adalah lokasi perairan tempat kapal berlabuh, mengisi perbekalan, atau melakukan aktivitas bongkar-muat. Kolam pelabuhan merupakan fasilitas pokok yang memiliki pengaruh besar terhadap fungsi pelabuhan (Ilham, Thaib dan Rahmah, 2016). Menurut Beny A.S. (2011), kolam pelabuhan adalah perairan yang berada di depan dermaga yang digunakan untuk bersandarnya kapal. Secara fungsional batas-batas kolam pelabuhan sulit ditentukan dengan tepat, tetapi secara teknis kolam pelabuhan dibatasi oleh daratan, pemecah gelombang, dermaga, atau batas administrasi pelabuhan. Luas kolam pelabuhan harus cukup menampung kapal yang tambat labuh setiap harinya. Oleh karena itu, dibutuhkan perencanaan dan perhitungan yang matang guna menentukan tingkat kebutuhan dari fasilitas fasilitas yang akan dikembangkan (Ramziah, Lubis, Muningar, 2012) 
Perairan kolam harus memiliki kedalaman yang cukup supaya kapal-kapal dapat keluar-masuk dengan aman pada saat air surut terendah (LLWL). Kedalaman kolam dihitung dengan persamaan di bawah ini.

$$
\mathbf{D}=\mathbf{d}+\mathbf{. H}+\mathbf{S}+\mathbf{C}
$$

dimana:

$\mathrm{D}=$ kedalaman kolam pelabuhan pada saat surut terendah.

$\mathrm{d}=$ draft kapal terbesar yang direncanakan akan menggunakan pelabuhan tersebut pada saat muatan penuh.

$\mathrm{H}=$ tinggi gelombang rencana dalam kolam pelabuhan.

$\mathrm{S}=$ squat $=$ pertambahan draft kapal akibat ayunan vertikal ketika kapal memasuki peraiaran dangkal.

$\mathrm{C}=$ keel clearence sebagai pengaman, diambil nilai-nilai $25-100 \mathrm{~cm}$ tergantung kondisi tanah dasar kolam.

\section{Kolam Putar (Turning Basin)}

Kawasan kolam tempat kapal melakukan gerak putar untuk berganti haluan harus direncanakan sedemikian rupa sehingga memberikan ruang cukup luas dan kenyamanan (Hermawati dan Buwono, 2012). Diameter putar turning basin yang ideal adalah:

$$
\text { D }>3 \text { Loa }
$$

dimana:

$\mathrm{D}=$ diameter kolam putar

Loa $=$ panjang kapal maksimum.

Luas areal kolam putar :

$$
A=1 / 4 * \text { phi*D2 (m2) }
$$

dimana:

$\mathrm{A}=$ luas kolam putar.

Loa $=$ panjang kapal maksimum.

$\mathrm{Phi}=3,14$

\section{Areal Berlabuh}

Areal tempat berlabuh adalah tempat di mana kapal diam menunggu waktu merapat ke dermaga. Luas areal yang dibutuhkan dihitung dengan rumus sebagai berikut:

$$
R=L o a+6 D+30
$$

$\mathrm{R}$ : Jari-jari areal untuk labuh per kapal

Loa : Panjang kapal yang berlabuh

D : Kedalaman air 


\section{Luas Areal Berlabuh $=\operatorname{Loa}+6 D+30 \times \pi \times R^{2}$}

Luas tersebut merupakan luas minimal dengan bentuk lingkaran. Luas aktual yang dibutuhkan akan lebih besar dari luas ini dengan memplot daerah dengan bentuk yang tidak lingkaran dan dikombinasikan dengan kebutuhan kapal dalam bermanuver ketika memasuki daerah labuh tersebut.

3. Metode penelitian

Jenis penelitian ini adalah penelitian deskriptif-evaluatif, dengan pendekatan kualitatif. Penelitian deskriptif dapat diartikan sebagai proses pemecahan masalah yang dianalisa dengan menggambarkan keadaan obyek penelitian pada saat ini berdasarkan fakta-fakta yang nampak atau kondisi eksisting (Fisu, 2016). Pelaksanaan metode penelitian deskriptif tidak terbatas sampai pada pengumpulan dan penyusunan data, tetapi meliputi analisis untuk mengetahui permasalahan (Fisu, 2018), yang dalm hal ini adalah kebutuhan fasilitas pelabuhan. Kemudian setelah data diolah dan dianalisis, maka dilakukan proses evaluatif dengan output berupa seberapa besar kebutuhan fasilitas sisi perairan pelabuhan. Adapun langkah-langkah untuk menganalisis kebutuhan fasilitas pelabuhan terlebih dahulu dianalisis kebutuhan listrik, jumlah batu bara yang dibutuhkan untuk memproduksi listrik, jenis kapal yang digunakan untuk mengangkut batu bara tersebut, perencanaan terminal khusus dengan analisis proyeksi volume bongkar muat, dan frekuensi kunjungan kapal di terminal khusus. Selanjutnya dilakukan analisis kebutuhan fasilitas laut atau perairan.

\section{Hasil dan Pembahasan}

a. Kebutuhan batu bara PLTU Nagan Raya

Berdasarkan target produksi energy di PLTU Nagan Raya, yaitu 75\% dari 5.280.000 Kwh, atau 5.280 MWh per hari, yaitu sebesar 3.960.000 Kwh atau 3.960 MWh per hari maka dapat diprediksi kebutuhan batubara dalam rangka pemenuhan target produksi energy tersebut.

Diketahui bahwa untuk menghasilkan 1Kwh energy listrik, dibutuhkan 2.998,5 Kkal. Dengan kualitas batubara yang akan digunakan oleh PLTU Nagan Raya adalah sekitar $4200 \mathrm{Kkal} / \mathrm{Kg}$, maka kebutuhan batubara untuk menghasilkan 1Kwh adalah: 
Fuel Heating value $=4200 \mathrm{KCal} / \mathrm{kg}$

$$
\begin{aligned}
& V=\frac{3.960 .000 \times 2988,5}{4200} \\
& V=2.817 .728,57 \mathrm{~kg} / \text { day } \\
& V=2.818 \mathrm{ton} / \text { day }
\end{aligned}
$$

artinya dalam satu hari produksi, dibutuhkan sekitar 2.818 ton batubara.

b. Proyeksi arus muatan Batu Bara dan kapal pengangkut

Pasokan batu bara untuk Pembangkit Listrik Tenaga Uap Nagan Raya, Aceh nantinya harus mendapatkan perhatian khusus, agar tidak mengalami keterlambatan yang berakibat pada terganggunya operasional pembangkit. Keterlambatan pasokan batubara yang berakibat pada terganggunya operasional pembangkit tentu saja akan berdampak pada terganggunya proses produksi energy listrik.

Kegiatan pembangunan dan pengembangan infrastruktur perlu pengkajian mendalam dari berbagai sisi, termasuk aspek daya dukung lahan dan aspek tata ruang (Fisu, 2019). Di sisi lain pertumbuhan aktivitas ekonomi akan mempengaruhi permintaan terhadap transportasi yang lebih banyak (Fisu, 2019), pembangunan atau pengembangan sarana transportasi juga dapat menimbulkan dampak positif terhadap suatu wilayah (Fisu, 2018).

PLTU Nagan Raya (2x110 MW) dalam rencana pengoperasiannya, mendapatkan pasokan batubara dari Pulau Kalimantan, tepatnya Provinsi Kalimantan Selatan. Posisi Pulau Kalimantan yang menjadi salah satu produsen batubara ini cukup strategis sebagai pemasok mengingat secara geografis letaknya tidak cukup jauh dari letak PLTU Nagan Raya (2x110 MW) yang berada di bagian Selatan Aceh Dengan kebutuhan batubara sekitar 2818 ton per hari. Oleh karena itu, di dalam rencana pengoperasian PLTU Nagan Raya (2x110 MW), setidaknya mendapat pasokan batubara sebanyak 84.532 ton dalam waktu sebulan (30 hari). Dengan menggunakan kapal yang memiliki kapasitas angkut 50.000 ton, maka jumlah 
kunjungan kapal dapat dilihat pada perhitungan di bawah ini:

$$
\begin{aligned}
\text { Jumlah Kunjungan kapal } & =\frac{\text { kebutuhan batubara }}{\text { kapasitas angkut kapal }} \\
& =\frac{84.532}{50.000} \\
& =1,69
\end{aligned}
$$

Dengan perhitungan tersebut, maka direncanakan kunjungan kapal 15 - 25 hari sekali dengan kapasitas angkut 50.000 ton. Atsu sekitar 2 kali dalm sebulan. Dengan demikian, maka jumlah kunjungan kapal pemasok batubara ke PLTU Nagan Raya Aceh dalam setahun sekitar 24 kunjungan kapal.

Dalam system pengangkutannya, kapal pengangkut batubara kemudian tidak berlabuh pada pelabuhan tarsus, namun menunggu di perairan PLTU untuk kemudian dilakukan aktifitas transshipment dengan menggunakan tongkang dan tug-boat lalu kemudian dibawa ke tarsus/PLTU. Tongkang dan tug-boat yang beroperasi untuk aktifitas transshipment masing-masing berjumlah dua unit dengan kapasitas tongkang saat ini dapat memuat hingga 2000 ton. Aktifitas transshipment ini berlangsung selama 24 jam dalam jangka waktu 15 - 25 hari, dengan rata-rata 14-18 kali transhipment tergantung muatan yang diangkut oleh kapal.

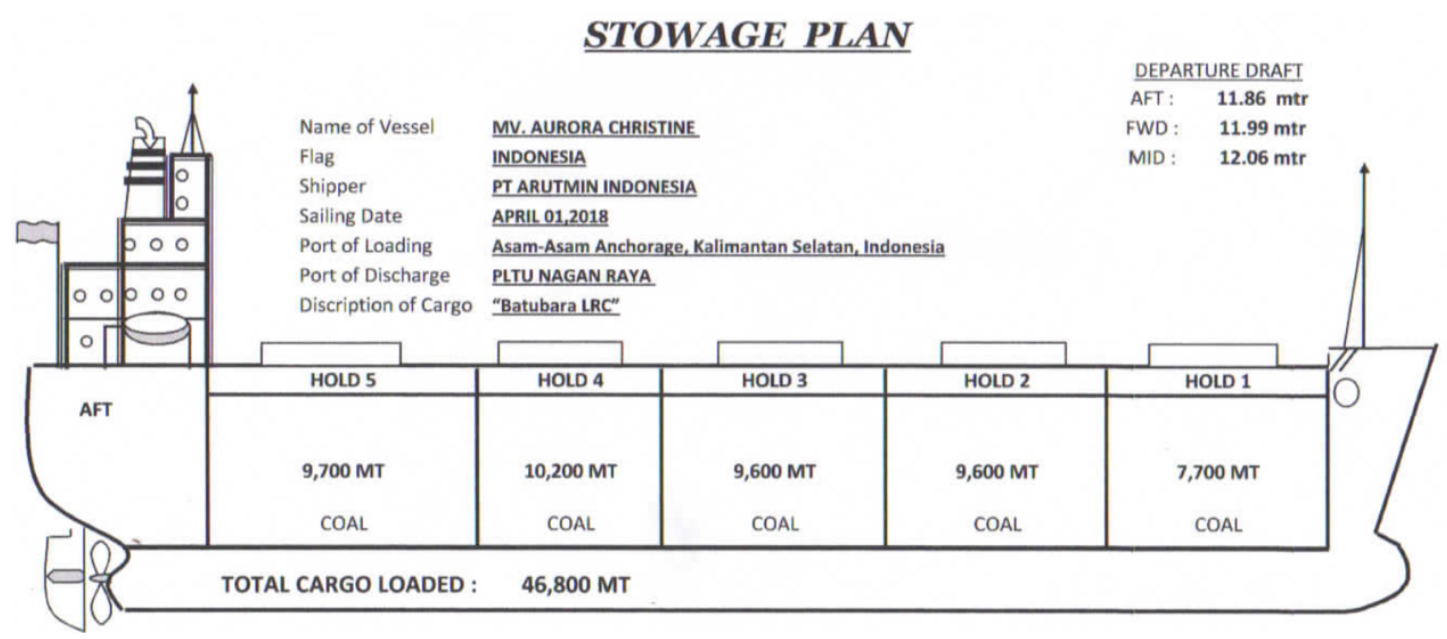

Gambar 3 : Spesifikasi Salah satu kapal pengangkut batubara yang beroperasi di 


\section{PLTU Nagan Raya}

\section{c. Rencana Prasarana Pelabuhan Tersus PLTU Nagan Raya}

Terminal khusus PLTU Nagan Raya direncanakan sebagai fasilitas yang dibutuhkan untuk mendukung aktifitas operasional PLTU Nagan Raya. Oleh karena itu, fasilitas yang akan disediakan digunakan untuk terminal khusus dan kebutuhan logistik. Rencana pemanfaatan ruang tersebut akan terbagi menjadi beberapa Kawasan yaitu alur pelayaran, area kolam putar, tempat sandar kapal, dan area labuh kapal.

Berdasarkan hasil analisis diperoleh kebutuhan fasilitas sisi laut seperti yang dapat dilihat pada table di bawah ini:

Tabel 1. Rencana Pengembangan Prasarana Darat Pelabuhan Khusus Batubara PLTU NAGAN RAYA

\begin{tabular}{|c|l|c|c|c|c|}
\hline \multirow{2}{*}{ Jenis Dermaga } & \multicolumn{1}{|c|}{ Uraian } & Satuan & $\begin{array}{c}\text { Jangka Pendek } \\
(2016-2021)\end{array}$ & $\begin{array}{c}\text { Jangka Menengah } \\
(2021-2026)\end{array}$ & $\begin{array}{c}\text { Jangka Panjang } \\
(2026-2036)\end{array}$ \\
\hline \multirow{5}{*}{ Batubara } & Lapangan Penumpukan & $\mathrm{m} 2$ & 13.600 & 13.600 & 13.600 \\
\cline { 2 - 6 } & Dimensi Dermaga & $\mathrm{m}$ & $20 \times 125$ & $20 \times 125$ & $20 \times 125$ \\
\cline { 2 - 6 } & Jumlah Dermaga & $\mathrm{buah}$ & 1 & 1 & 1 \\
\cline { 2 - 7 } & Kantor & $\mathrm{m} 2$ & 100 & 100 & 100 \\
\cline { 2 - 7 } & bengkel Pemeliharaan & $\mathrm{m} 2$ & 500 & 500 & 500 \\
\hline
\end{tabular}

Selain prasarana darat pada tabel di atas, pelabuhan membutuhkan prasarana laut yang dapat dilihat pada table di bawah ini

Tabel 2. Rencana Pengembangan Prasarana Laut Pelabuhan Khusus Batubara PLTU NAGAN RAYA

\begin{tabular}{|c|c|c|c|c|}
\hline No. & Nama Areal & Parameter & Rumus Pendekatan & Kebutuhan Areal \\
\hline \multirow[t]{4}{*}{1} & \multicolumn{4}{|l|}{ Areal Alur Pelayaran } \\
\hline & -Lebar alur pelayaran & $\mathrm{B}=$ Lebar kapal (m) & $\mathrm{W}=5 \mathrm{~B}+30$ & $\mathrm{~W}=95 \mathrm{~m}$ \\
\hline & $\begin{array}{l}\text {-Kedalaman Alur } \\
\text { Pelayaran }\end{array}$ & $\mathrm{D}=$ Draft Kapal & $\mathrm{d}=\left(1.25^{*} \mathrm{D}\right)+1.5$ & $\mathrm{~d}=11.5 \mathrm{~m}$ \\
\hline & - Luas Areal Alur & $\mathrm{La}=$ Panjang Alur & $\mathrm{A}=\mathrm{W} * \mathrm{~L}$ & $\mathrm{~A}=2.268 \mathrm{~m}^{2}$ \\
\hline
\end{tabular}




\begin{tabular}{|c|c|c|c|c|}
\hline No. & Nama Areal & Parameter & Rumus Pendekatan & Kebutuhan Areal \\
\hline & $\left(\mathrm{m}^{2}\right)$ & $\begin{array}{l}\quad=18 \times \text { panjang } \\
\text { kapal } \\
\text { terbesar } \\
\mathrm{W}=\text { lebar alur } \\
\text { pelayaran }\end{array}$ & & $\mathrm{A}=0.23 \mathrm{Ha}$ \\
\hline 2 & Areal Kolam Putar & $\begin{array}{l}\mathrm{L}=\text { Panjang kapal } \\
(\mathrm{LOA}) \text { terbesar } \\
\mathrm{D}=\text { diameter Areal } \\
\text { kolam putar } \\
\mathrm{H}=\text { Kedalaman Kolam } \\
\text { D=Diameter Kolam } \\
\text { putar }\end{array}$ & $\begin{array}{l}\mathrm{D}=3 \mathrm{~L} \\
\mathrm{~A}=0.25^{*} \mathrm{pi}^{*} \mathrm{D}^{2} \\
\mathrm{H}=\text { Draft }+1 / 2 \mathrm{H}+\mathrm{S}+\mathrm{C}\end{array}$ & $\begin{array}{l}D=224 \\
A=392 \mathrm{~m} 2 \\
H=4.5 \mathrm{~m}\end{array}$ \\
\hline
\end{tabular}

Rencana pengembangan sarana pelabuhan dalam rangka pengembangan Pelabuhan Khusus Batubara PT. PLN (Persero) ini meliputi peralatan untuk proses pengolahan batubara dan proses loading ke ponton. Rincian peralatan tersebut dapat dilihat pada di bawah ini:

Tabel 3. Fasilitas Peralatan PLTU NAGAN RAYA

\begin{tabular}{|c|c|c|c|}
\hline No & Nama Peralatan & Kapasitas & Jumlah Unit \\
\hline 1 & Prima Crusher & $1.000 \mathrm{Ton} / \mathrm{Jam}$ & 1 Unit \\
\hline 2 & Secondary crusher & $1.000 \mathrm{Ton} / \mathrm{Jam}$ & 1 Unit \\
\hline 3 & Stockpile - ROM & 80.000 Ton & 1 Unit \\
\hline 4 & Stockmile Product & 30.000 Ton/Unit & \\
\hline 5 & Discharging Conveyor & Panjang $593 \mathrm{~m}$ & 1 Unit \\
\hline 6 & Barge Loader & $2.000 \mathrm{Ton} / \mathrm{Jam}$ & 1 Unit \\
\hline 7 & Reclaimer & $2.000 \mathrm{Ton} / \mathrm{Jan}$ & 4 Unit \\
\hline 8 & Chain Conveyor & Panjang 349 m & 1 Unit \\
\hline 9 & Power House & $5 \times 500 \mathrm{KVA}$ & 1 Unit \\
\hline
\end{tabular}




\begin{tabular}{|c|l|c|c|}
\hline No & \multicolumn{1}{|c|}{ Nama Peralatan } & Kapasitas & Jumlah Unit \\
\hline 10 & Tanki Solar & 1.000 Kilo Liter & 1 Unit \\
\hline 11 & Bulldozer & $215-335 \mathrm{HP}$ & 3 Unit \\
\hline 12 & Wheel Loader & $3.50-4.00$ & 3 Unit \\
\hline 13 & Dump Truck & 30 Ton & 6 Unit \\
\hline 14 & Motor Grader & $155 \mathrm{HP}$ & 2 Unit \\
\hline 15 & Excavator & $1.20-2.30 \mathrm{~m}$ & 1 Unit \\
\hline 16 & Vibro Roller & 10 Ton & Unit \\
\hline
\end{tabular}

Meskipun sarana dan peralatan yang telah dijelaskan di atas terdapat pada wilayah pelabuhan, namun pada hakikatnya sarana dan peralatan tersebut adalah merupakan bagian dari PLTU NAGAN RAYA. Karena perencanaan pelabuhan ini pun merupakan bagian dari PLTU NAGAN RAYA. Sehingga dapat dikatakan bahwa tidak semua sarana dan peralatan tersebut bukan merupakan bagian langsung dari pelabuhan ini, namun merupakan bagian langsung dari PLTU NAGAN RAYA

\section{REFERENCES}

Adireta Dwi Witantono dan Khosmin. (2015), "Permodelan Aliran Sedimen di Kolam pelabuhan (Studi kasus: Kolam 1 Pelabuhan Tanjungpriok, Jakarta), Geoid Journal of Geodesy and Geomatics. Vol.11, No.1, 22-28.

Arianto Dedy. (2017), "Evaluasi Pengembangan Pelabuhan Sibolga". Jurnal Penelitian Transportasi Laut 19 2017, 1-13.

Beny A.S. (2011), "Peranan Fasilitas Pelabuhan Dalam Menunjang Kegiatan Bongkar Muat Di Divisi Terminal Jamrud PT. Pelindo III Tanjung Perak, Surabaya”. Jurnal Aplikasi Pelayaran dan Kepelabuhanan, Vol.02 No.01 September 2011. 52-68.

Fisu AA. (2018). "Analisis Kebutuhan Fasilitas Sisi Laut Pelabuhan Terminal Khusus PLTGU Lombok”. Jurnal Pena Teknik Vol.02 No.02, September 2018. $53-65$

Fisu AA. (2019). "Analisis Potensi Ekosistem Mangrove Sebagai Pengembangan Objek Wisata (Studi Kasus: Kabupaten Wakatobi)". Prosiding Seminar Nasional UNCP Buku 2. Vol 2 No 1.

Fisu AA. (2018). “Analisis Lokasi Pada Perencanaan Terminal Topoyo, Mamuju Tengah". Jurnal Pena Teknik Vol.02 No.01 2018

Fisu AA. (2016). "Potensi Demand pengembangan Kanal Jongaya \& Panampu Sebagai Moda Transportasi Kota Makassar". Jurnal JMTranslog Trisakti Vol 03 
no 03, Jakarta.

Fisu AA. (2016). “Analisis dan Konsep Perencanaan Kawasan Pelabuhan Kota Penajam sebagai Pintu Gerbang kab. Penajam Paser Utara, Kalimantan Timur”. Jurnal Pena Teknik Vol.01 No.02 September 2016. 125-136.

Fisu AA. (2019). "Identifikasi Awal Lokasi Rencana Pelabuhan Di Teluk Prigi Kabupaten Trenggalek". https://osf.io/preprints/inarxiv/c82h6/

Fisu AA. (2019). "Studi Awal Lokasi Rencana Pelabuhan Di Teluk Prigi Kabupaten Trenggalek". https://osf.io/preprints/inarxiv/p5ec4/

Fisu AA. (2019). Analisis Kelayakan Ekonomi \& Finansial pada Masterplan Kawasan Industri Perikanan Kota Tarakan. https://doi.org/10.31227/osf.io/96yzu.

Fisu AA. (2019). “Tinjauan TransportasiPada Kawasan Komersil (Studi Kasus Jalan Cihampelas Kota Bandung)". https://doi.org/10.31227/osf.io/s9u2a

Hermawati dan Haryo Koco Buwono. (2012). “ Analisis Kelayakan Kebutuhan Pelabuhan dan Keselamatan Pelayaran Pelabuhan Bian Kabupaten Merauke". Jurnal Konstruksia Vol.03 No.02 April 2012. 1-12.

Humang Windra Priatna \& Zulfadly, (2016,) “Analisis Keterpaduan Moda Transportasi Angkutan Penyeberangan Dengan Jalan Raya di Pelabuhan Bajoe Kab. Bone", Jurnal Pena Teknik Universitas Andi Djemma, Palopo.

Muchraja Ilham, Rizwan Thaib, Alvi Rahmah. (2016). “ Kelayakan Luas Kolam Pelabuhan Perikanan Pantai Lampulo Kurun Waktu 10 Tahun Kedepan”. Jurnal Ilmiah Kelautan dan Perikanan Unsyiah, Vol.01 No.03 November 2016. 374-387

Rio Oktaparizki, Eldina Fatimah, Azmeri. (2018), "Faktor Pengembangan Sarana dan Prasarana Pelabuhan Penyeberangan Ulee Lheue". Jurnal Teknik Sipil Universitas Syiah Kuala, Vol.01 Special Issue, No.04 2018. 953-960

Ramziah An Najah, Ermani Lubis, Retno Muninggar. (2012). "Keberadaan Fasilitas Menurut Aktivitas diPelabuhan Perikanan Pantai Lampulo, Banda Aceh", Marine Fishers Vol.03 No.01, Mei 2012 55-70. 